\title{
A VIDA NA ARTE: A VERBIVOCOVISUALIDADE DO GÊNERO FILME MUSICAL
}

\section{LIFE IN ART: THE VERBAL-VOCAL-VISUALITY OF THE MUSICAL FILM GENRE}

Luciane de Paula 97 Nicole Mioni Serni ${ }^{98}$

\begin{abstract}
RESUMO: Este texto reflete acerca da concepçâo de gênero discursivo, tendo como base tanto a sua mobilidade quanto a sua estabilizaçấo. Para isso, centra-se na exemplificaçáo de um gênero específico: o filme musical. Este, visto como gênero fértil para o estudo de diálogos entre gêneros (intergenericidade), voltados ao sincretismo verbo-voco-visual. No filme musical, a cançấo e a coreografia se retroalimentam, bem como, de certa forma, alicerçam o filme (e este, encontra-se fincado na vida, refigurando-a simbolicamente, com acabamento estético). Pretende-se fazer uma breve discussấo epistemológica sobre a concepçăo de gêneros discursivos e a relaçâo arte e vida para, depois, a partir de uma rápida ilustraçáo com um pequeno exemplo de Across the Universe colocar a discussâo acerca da constituiçăo do gênero discursivo filme musical à baila. Toda a reflexăo está calcada na abordagem dialógica do Círculo Bakhtin, Medviédev e Volochínov. Refletir sobre a constituiçấo verbivocovisual do gênero filme musical é uma maneira de se pensar a relativa estabilidade dos gêneros na contemporaneidade.
\end{abstract}

Palavras-chave: Círculo de Bakhtin; gênero; discurso; verbivocovisualidade; filme musical.

ABSTRACT: This text reflects about the concept of discoursive genre, having as basis its mobility as much as its stabilization. For that, this work centers on the exemplification of a specific genre: the musical film. This one, here considered as a fertile genre for the dialogic studies between genres (intergenres), focused on the verb-vocal-visual syncretism. In: the musical film, the song and the choreography feed one another as well as, in a certain way, enhance the movie (and this one, finds itself settled in life, symbolically reframing it, with aesthetic finishing). This research intends to create a brief epistemological discussion about the conception of discursive genres and the relation between art and life, so that afterwards, from a quick illustration with

97 Docente da Universidade Júlio de Mesquita Filho - UNESP, campus de Assis, e do Programa de Pós-Graduaçấo em Linguística e Língua Portuguesa da UNESP, campus de Araraquara. E-mail: lucianedepaula1@gmail.com

98 Doutoranda na Universidade Júlio de Mesquita Filho - UNESP, campus de Araraquara. E-mail: nicole_ brass2@yahoo.com.br 
an example from Across the Universe, the constitution of the musical film is put into discussion. All the reflection is based on the dialogic perspective of the Circle Bakhtin, Medvedev, Volochinov. To think about the verb-vocal-visual constitution of the musical film genre is a way to discuss the relative stability of genres in the contemporaneity.

keywords: Bakhtin Circle; genre; discourse; verbal-vocal-visuality; musical film.

\section{INTRODUÇÃO}

Desde o primeiro filme considerado "musical", O Cantor de Jazz, de 1927, de Alan Crosland, até os dias atuais, foram criadas diversas (re)leituras desse gênero fílmico que possui, essencialmente, a cançăo no interior de suas tramas. Mais que incorporada, a cançăo se faz presente nesse tipo de construçăo fílmica de maneira constitutiva. Sem ela, o gênero musical inexiste. Ora a serviço do enredo ou de algum personagem, ora como protagonista - com o enredo todo ou cenas ou algumas falas voltadas a ela -, a cançăo faz parte da arquitetônica do musical. Logo, mais que uma reles incorporaçáo de um gênero por outro, a cançăo integra a composiçăo do musical. Nesse sentido é que o presente artigo busca refletir sobre a especificidade do filme musical tendo como foco principal a sua constituiçâo intergenérica ${ }^{99}$ (a importância da cançăo ou da música na arquitetônica ${ }^{100}$ do filme). $O$ estudo do filme como intergenérico possui como objeto delimitado ilustrativo o filme Across the Universe ${ }^{101}$ (2007), de Julie Taymor, que, em sua construçăo, é constituído apenas por cançóes da banda britânica The Beatles. Estudar a construçấo do musical é relevante para o estudo dos gêneros discursivos, dada a sua característica verbivocovisual.

Este artigo está fundamentado nos estudos bakhtnianos sobre gêneros. Ainda que Bakhtin tenha se voltado em especial à verbalidade (especificamente ao gênero romanesco no campo da literatura), as reflexôes empreendidas por ele se voltam à linguagem como um todo, inclusive, em diversas obras, o filósofo deixa clara a importância de estudos voltados à música e à visualidade de forma integrada com o verbal. Tendo como foco a amplitude da perspectiva bakhtiniana é que este texto se volta ao gênero fílmico, calcado em sua constituiçăo verbivocovisual.

O termo verbivocovisual foi cunhado por James Joyce e utilizado de maneira metafórica por Décio Pignatari para tratar da linguagem da poesia concreta. Também se utiliza aqui a expressăo de maneira metafórica, pois ela năo só abarca como explicita as dimensōes constituintes da linguagem, como pensada pelo Círculo de Bakhtin. A

99 A questâo dos intergêneros, estudada por Paula (2012), é aqui entendida como uma situaçâo em que dado gênero faz parte da composiçăo de outro de maneira constitutiva essencial. Sem essa retroalimentaçâo, năo há intergenericidade. Năo será considerado intergênero o caso de simples presença de um gênero no interior de outro (considerado esse mecanismo como incorporaçăo genérica), mas sim um gênero como parte da construçấo arquitetônica de outro (gênero), alterando-o. Este é o caso da cançăo, por exemplo, formada pela e na intersecçáo entre os gêneros orais: letra e música.

100 Ao se utilizar "arquitetônica", aqui, o conceito é compreendido como a análise do "todo" do objeto em questăo, no caso, a construçăo do filme musical. Ainda que sejam feitos recortes de cenas e cançôes como semiose simbólica da unidade genérica, a análise se liga à composiçăo do filme considerando-o em seu todo.

101 A análise desse filme foi tema da dissertaçăo de mestrado de Serni (2013), defendida sob a orientaçăo de Paula. 
verbivocovisualidade diz respeito ao trabalho, de forma integrada, das dimensóes sonora, visual e o(s) sentido(s) das palavras. $O$ enunciado verbivocovisual é considerado, em sua potencialidade valorativa. Esse é o ponto de partida sobre o qual se desenvolve as consideraçóes sobre a pertinência da teoria bakhtiniana para a análise da verbivocovisualidade, tema sobre o qual se reflete aqui, com um breve exemplo de análise.

O enunciado ${ }^{102}$ fílmico pode se subdividir em tipos específicos que revelam a forma composicional cinematográfica e o estilo autoral de cada diretor e produtor. Investigar como a arquitetônica do musical é composta é a preocupaçăo deste artigo. A escolha por pesquisar esse tipo de filme apareceu em funçăo do questionamento acerca de como ocorre a sua constituiçăo, uma vez que ele é marcado, de maneira mais declarada, já destacada em sua designaçăo, por outros gêneros, a cançăo e a música. O filme musical demonstra como as formas típicas de enunciados de outros gêneros, conforme explica Bakhtin (2003) acerca da concepçâo de gênero, sâo incorporadas à sua arquitetura e podem lhe alterar as características. O trabalho com a análise do filme musical permite o estudo das formas de incorporaçâo de diferentes genericidades pelo cinema, bem como permite pensar que alguns gêneros, mais que incorporados, constituem a forma composicional do enunciado fílmico, dando a ele características específicas.

Across the Universe traz em seu interior a cançâo como outro gênero que constitui uma especificidade fílmica: o musical. A importância do presente trabalho se encontra na contribuiçâo que se pretende realizar para o entendimento da formaçáo de gêneros a partir da relaçăo com outros gêneros, como concebe Bakhtin (idem). O filme em questăo pode ser reconhecido como um exemplar de musical, dada a peculiaridade da presença da cançáo na construçâo da narrativa (como fala das personagens, constituição cênica, trilha sonora e também expressâo temática narrativa), elemento essencial do enunciado fílmico. As variaçóes no interior da formaçăo dos gêneros demonstram a sua relativa estabilidade, pois, se por um lado, o musical preserva características e utiliza técnicas cinematográficas de construçăo (enquadramento, iluminaçăo, encenaçăo, entre outras), ou seja, năo deixa de ser filme; por outro, ele assume uma especificidade, a música e a cançáo, a dança e a coreografia aparecem como elementos fundamentais que constituem esse tipo de enunciado, ou seja, uma maneira (forma) particular de filme.

Se, para o Círculo russo, os gêneros sâo relativamente estáveis, tem-se de considerar tanto sua estabilidade quanto a possibilidade de ruptura com tal estratificaçăo, pois é ela que gera, segundo Sobral (2011), outros tipos ou mesmo outros gêneros, dada a gama de possibilidades de construçấo enunciativa, que leva em consideraçăo o estilo autoral e a forma composicional dos gêneros, pensados em sua arquitetônica, nas esferas de atividade em que sâo produzidos e circulam, bem como para que fim e que público e em que circunstâncias săo recebidos.

102 Enunciado é aqui compreendido como toda forma de interaçâo verbal, de maneira ampla. De acordo com Brait, para Bakhtin (apud BRAIT), "O enunciado [...] é concebido como unidade de comunicaçăo, como unidade de significaçâo, necessariamente contextualizado. Uma mesma frase realiza-se em um número infinito de enunciados, uma vez que săo únicos, dentro de situaçōes e contextos específicos" (BRAIT, 2010, p. 63). O enunciado é, desse modo, um todo de sentido, que possui acabamento, é responsivo e tem natureza dialógica. As relaçōes entre enunciados criam uma espiral de ligaçôes entre eles, ininterrupta, sempre em processo, ampliando-se. A constituiçâo de Across the Universe faz parte da espiral dialógica de enunciados-respostas e respostas-enunciadas, e seus possíveis diálogos nâo seráo finalizados ao longo deste texto, mas no item 3, utilizados brevemente como exemplos de reflexâo sobre a composiçáo do gênero filme musical e este, visto como refiguraçăo da vida em forma de enunciado artístico. 
A cançăo, gênero presente, de forma constitutiva essencial, de maneira especial no musical, é considerada intergenérica por Paula (2012), pela sua constituiçâo de fusâo entre letra, música e performance. No filme, a cançăo é um gênero integrante da arquitetônica enunciativa (nâo se trata aqui de pensar a trilha sonora, presente na maior parte dos filmes - este seria um caso de incorporaçăo simples de um gênero por outro. No musical, mais que incorporaçăo, a cançăo e/ou a música compóem o enunciado fílmico), uma vez que desempenha(m) papéis próprios da narrativa: ora ela(s) estrutura(m) falas de personagens, ora assume(m) a funçâo do narrador junto com a câmera etc.

A composiçāo fílmica do musical é intergenérica porque se caracteriza como parte integrante da sua produçấo: diferente de outros filmes, em que a cançâo ou a música podem ser retiradas sem grande dano à narrativa e à constituiçấo do enunciado, no musical, a retirada da cançăo ou da música é impensável, uma vez que, sem ela(s), muitas vezes, toda a narrativa se esvai, é destruída, já que ela(s) faz(em) parte da forma composicional do próprio enunciado fílmico. Assim, a cançăo, como explica Paula (idem), como um gênero, é um dos grandes elementos de construçăo do filme musical. A sua presença, da maneira como se apresenta nesse tipo de produçāo específica, é, de fato, constitutiva, pois parte essencial da formaçăo do filme musical, como será visto no exemplo analítico de uma sequência de Across the Universe.

\section{CLAQUETE: A NOÇÃO DE GÊNEROS DISCURSIVOS}

A partir de Bakhtin, os estudos dos gêneros săo ampliados para interaçôes de enunciados sem preocupaçăo de hierarquizaçăo, como anteriormente ocorria (desde Aristóteles, a ideia dos estudos que se focavam nos gêneros pensava em classificaçôes típicas). Segundo Machado (2010, p. 152), graças à concepçấo de gêneros do discurso do Círculo é que se é possível:

[...] considerar as formaçôes discursivas do amplo campo da comunicaçâo mediada, seja aquela processada pelos meios de comunicaçáo de massas ou das modernas mídias digitais, sobre o qual, evidentemente, Bakhtin nada disse mas para o qual suas formulaçōes convergem.

Os gêneros incluem os diálogos cotidianos (chamados de gêneros primários) bem como enunciaçôes da vida pública, institucional, artística, científica e filosófica (consideradas gêneros secundários, a depender do seu acabamento - nascidos a partir dos gêneros primários, seja por incorporá-los seja por transformá-los), surgidos na esfera ${ }^{103}$ prosaica. Do ponto de vista do dialogismo, a prosa é uma das mais amplas

103 Para o Círculo, "a noçâo de esfera da comunicaçăo discursiva (ou da criatividade ideológica, ou da atividade humana, ou da comunicaçăo social, ou da utilizaçăo da língua, ou simplesmente ideologia) é compreendida como um nível específico de coerçōes que, sem desconsiderar a influência da instância socioeconômica, constitui as produçóes ideológicas, segundo a lógica particular de cada esfera/campo" (GRILLO, 2010, p. 143). O conceito de esfera, para o Círculo, considera a produçâo, a circulaçăo e a recepçâo de um gênero. A produçâo seria o projeto; a circulaçâo seria a maneira e por onde ele circula; e na recepçáo considera-se o público (que, por sua vez, também produz, em resposta, outros enunciados, do mesmo ou de outros gêneros). A esfera de um sujeito pode levá-lo a agir de certa maneira. Segundo Grillo, a esfera ou campo é um conceito importante para as pesquisas em gêneros discursivos, uma vez que a "relaçâo de um texto com outros da mesma espécie passa pela sua inserçấo em determinado domínio cultural, adquirindo um modo próprio de refratar a realidade em seus diversos aspectos" (2010, p. 156). 
formas culturais e, no interior dela, outras formas (inclusive de outras esferas) săo experimentadas. $O$ estudo bakhtiniano dos gêneros, tomados como formas relativamente estáveis, deve considerar também a importância do contexto comunicativo no qual cada gênero em questâo se encontra, o contexto em que é produzido, em que circula e no qual é recebido. Isso porque os gêneros săo formas comunicativas năo adquiridas em manuais, mas nos processos interativos. O gênero, segundo Machado (2005, p. 158), concebido como uso, com finalidades expressivas, năo é açăo deliberada, mas deve ser dimensionado como manifestaçâo da cultura. Afinal, "[...] é dispositivo de organizaçâo, troca, divulgaçăo, armazenamento, transmissăo e, sobretudo, de criaçăo de mensagens em contextos culturais específicos".

Para Bakhtin, os gêneros surgem em uma dada esfera e possuem uma forma, um estilo e um conteúdo específicos. Os gêneros têm características semelhantes que nos levam a reconhecê-los e atribuí-los a algum campo de conhecimento. No entanto, eles também possuem traços únicos, uma vez que a cada ato de cada gênero, em sua composiçâo, surgem mudanças, renovaçōes, e, dessa maneira, os estudos do Círculo consideram os gêneros năo apenas na sua estabilidade (classificatória), mas também na sua mobilidade, ou seja, em seu caráter instável. Para o Círculo, o jogo entre esses dois polos é o foco, ou seja, o movimento - o que năo exclui qualquer dos polos e nem transforma os estudos dos gêneros em uma rede de meras cristalizaçōes.

Certas características poderăo nos levar a reconhecer cada gênero como tal, no entanto, esses traços năo devem ser considerados como exigência para a denominaçáo de certo gênero, ou seja, năo existe uma fôrma em que um enunciado deve se encaixar para ser considerado de dado gênero, de forma fossilizada. Pelo contrário, o enunciado é encarado como um ato único que pode (re)formular os gêneros, pois reitera suas estabilidades e, ao mesmo tempo, altera-lhes por renová-los, ao considerar suas nuances e tons. Como afirma Bakhtin, "Evidentemente, cada enunciado particular é individual, mas cada campo de utilizaçâo da língua elabora seus tipos relativamente estáveis de enunciados, os quais denominamos gêneros do discurso." (2003, p. 262). Para o estudioso, os gêneros sâo relativamente estáveis porque se caracterizam tanto por sua estabilidade (particularidades em comum) quanto por sua instabilidade (renovaçóes e reconstruçōes no interior do próprio gênero, que podem modificá-lo com o tempo ou até criar um novo gênero).

Para o Círculo, "uma obra só se torna real quando toma a forma de determinado gênero." (MEDVIEDEV, 2012, p. 193). Desse ponto de vista, o filme é considerado um gênero discursivo (em geral, veiculado no cinema, mas năo só, principalmente se se considerar o momento contemporâneo, em que o filme circula por diversos suportes e adentra diversas esferas). O filme musical é materializado por meio do enunciado vocal (musical ou cancioneiro - inclusive, neste caso, materializado com determinada entoaçáo), com sua especificidade arquitetônica.

A cançăo é um gênero constitutivo do filme musical. A análise desse gênero necessita, portanto, da análise das cançóes que o compóem. Nos estudos da cançăo, podem-se considerar três tipos de sujeitos: o eu lírico, aquele que se expressa na letra da cançăo, tal qual na poesia - por exemplo, o sujeito que se toma como personagem do texto, no caso, letra de uma cançâo, palavra cantada; o intérprete, que será nâo aquele que "fala" no texto, mas sim o qual "dá voz" ao texto, interpreta/executa a cançăo, ou seja, aquele que entoa uma letra melodicamente; o compositor, autor-criador do texto, que nâo é o 
sujeito que "fala" nem o sujeito que entoa a cançăo, mas sim o enunciador, aquele que constrói a cançấo de acordo com o seu projeto de dizer e que pode ou nâo coincidir com o intérprete. No filme musical, o compositor nunca coincide com o eu lírico ou com o intérprete. No entanto, o eu lírico e o intérprete (personagem, nâo ator-pessoa) sempre se fundem, pois, na construçâo do musical, as personagens dâo vida às cançôes, e as letras por eles cantadas săo parte integrante da narrativa que compóe, muitas vezes, a personalidade da personagem.

As falas de cada personagem sâo, na maioria das vezes, cançôes, por isso o intérprete, aquele que "dá voz" à letra por meio de sua personagem, é também o eu lírico, que vivencia a trama entoada pela cançâo e, muitas vezes, parece ser o próprio enunciador (autor-criador projetado pelo autor-pessoa), no ato da entoaçâo, uma vez que parece construir o enunciado no ato da entoaçấo - ilusâo estética do filme, que simula as situaçôes narradas como presentes (característica típica do gênero cançâo, especialmente ao se pensar em sua performance ou execuçăo, segundo Paula, 2012).

Para o filósofo russo, os gêneros năo săo apenas um conjunto de fatores em comum, como se os requisitos para a existência de cada gênero surgissem antes do próprio, mas sim um olhar contemplativo de um sujeito que (re)cria e responde a uma realidade e esse ato enunciativo se materializa num gênero (nâo há enunciado solto, fora de qualquer gênero). Conforme Medviédev:

\begin{abstract}
O artista deve aprender a ver a realidade com os olhos do gênero. É possível entender determinados aspectos da realidade apenas na relaçăo com determinados meios de sua expressăo. Por outro lado, os meios de expressáo podem ser aplicados somente a certos aspectos da realidade. $O$ artista náo encaixa um material previamente dado no plano preexistente da obra. O plano da obra lhe serve para revelar, ver, compreender e selecionar o material (2012, p. 199).
\end{abstract}

Para que um enunciado seja considerado gênero, Bakhtin aponta três características: forma, estilo e conteúdo. Na forma săo pensadas as diversas maneiras como as construçōes aparecem, enquanto no estilo e no conteúdo transparecem, respectivamente, o sujeito autoral e o tema. $O$ estudo da constituiçăo dos gêneros discursivos, conforme o filósofo russo, considera a singularidade de cada gênero em particular (forma composicional; material/conteúdo/tema; estilo identitário, do autor e do próprio gênero). O estilo năo é algo pessoal, mas sim autoral. Características pessoais de um sujeito năo justificam seu estilo como sujeito de linguagem, mas os traços estilísticos do autorcriador, de certa forma, "definem" uma obra por identificá-la por meio de seu projeto de dizer. Afinal, "cada esfera conhece gêneros apropriados a suas especificidades. A esses gêneros correspondem determinados estilos." (BRAIT, 2010, p. 89.)

\title{
CÂMERA: O FOCO NA VIDA E NA ARTE
}

Bakhtin trata dos gêneros em dois grupos que se retroalimentam: primários e secundários:

Os gêneros discursivos secundários (complexos - romances, dramas, pesquisas científicas de toda espécie, os grandes gêneros publicísticos, etc.) surgem nas condiçóes de um convívio cultural mais complexo e relativamente muito desenvolvido e organizado (predominantemente o escrito) - artístico, científico, sociopolítico, etc. (2003, p. 263) 
Essas denominaçôes nâo visam à hierarquizaçăo, mas o reconhecimento de dois núcleos distintos de criaçōes de gêneros do discurso:

\begin{abstract}
Durante o processo de sua formaçăo, os gêneros secundários absorvem e assimilam os gêneros primários (simples) que se constituíram na comunicaçăo discursiva imediata. Os gêneros primários, ao integrarem os gêneros secundários, transformam-se e adquirem uma característica particular: perdem sua relaçăo imediata com a realidade dos enunciados alheios. (BAKHTIN, 2003, p. 62)
\end{abstract}

Os gêneros surgem, dessa maneira, um partir do outro, do contato entre eles nas esferas de atividades. Machado afirma que "Para Bakhtin, os gêneros discursivos sinalizam as possibilidades combinatórias entre as formas da comunicaçăo oral imediata e as formas escritas. Gêneros primários e secundários săo, antes de mais nada, misturas." (2010, p. 161). Os gêneros primários seriam, dessa forma, aqueles do cotidiano, mais ligados à vida; enquanto os gêneros secundários estăo mais conectados às construçôes complexas, năo tăo espontâneas quanto os gêneros primários.

A cançăo, por exemplo, segundo Paula (2014), caracteriza-se como um simulacro imagético de retroalimentação à concepçáo de gênero tal qual pensada pelo Círculo, pois, ao mesmo tempo em que ela nasce do cotidiano, oral, como gênero primário; devido à elaboraçăo tanto verbal quanto musical (seja em consonância ou dissonância), ela (a cançâo) transforma-se em gênero secundário, uma vez que construída com dado acabamento. Todavia, no ato de sua execuçăo (a entoaçáo performática), a cançăo parece tanto semiotizar o cotidiano quanto dele se nutrir (via oralidade, refrăo com facilidade, dada repetiçâo sonora etc). Com isso, cria a ilusâo de ser primária.

O filme musical, contudo, năo possui esse mesmo sentido, pois, ao entoar melodicamente a narrativa, o sujeito perde a naturalidade da fala espontânea, assim como a movimentaçăo das personagens (que, no musical, é explicitada pela coreografia, bastante distante do "real"). O conjunto arquitetônico do musical (inclusive, năo apenas fílmico, mas também teatral - seja ele um musical da Broadway seja uma ópera) constrói um tom de artificialidade oposto ao efeito de sentido criado pela cançăo em outras situaçôes. Isso ocorre exatamente pelo uso excessivo de musicalidade e da movimentaçáo corporal coreográfica que compóem o enunciado fílmico, em essência. Nem todos săo tăo excessivos, pois há os que rompem com essa estabilidade, ainda que esses sejam traços típicos do gênero musical. Em Across the Universe, a coreografia aparece em alguns momentos e, em outros, ela fica ausente da narrativa. Clássicos como Cantando na chuva e Les Misérables (a montagem de 2012) sâo exemplos típicos de musicais que apresentam características bem distintas quanto à dança: este năo possui sequências coreográficas e é gravado com os atores cantando ao vivo (como no teatro), diferente daquele, em que tudo é expresso pela sapateado (a música e a canção aparecem como suporte para a dança, inclusive) e gravado por partes, em tomadas ensaiadas em estúdios com a música e a cançâo sobrepostas à interpretaçăo coreográfica.

Seja a cançâo produzida para outros fins, veiculada por outros suportes (o álbum, o DVD ou o clipe musical), deslocada para compor a trama de um filme (caso de cançôes de The Beatles em Across the Universe); seja um repertório musical ou cancioneiro composto especificamente para a narrativa fílmica (como é o caso de Les Misérables), quando ela (a cançáo) é introduzida no filme musical, mais que incorporada como trilha sonora para compor uma cena ou levar a determinada comoçăo, ela passa a fazer parte 
da trama e, tanto como fala das personagens quanto como voz do narrador ou ainda como composiçáo de determinado ambiente, ela passa a constituir o filme, com funçâo específica modificada de sua origem, pois intrínseca ao gênero, inclusive, nomeando-o.

Ao se refletir sobre a ligaçăo imprescindível existente entre arte e vida a partir dos estudos do Círculo, pode-se pensar o fazer artístico em diálogo de reflexo e, principalmente, de refraçấo permanente com o social, de onde surge. A arte e a vida seguem em constante conexăo, pois "A arte, também, é imanentemente social; o meio social extra-artístico [...] encontra resposta direta e intrínseca dentro dela" (VOLOCHINOV/ BAKHTIN, Mimeo, s/d, p. 2).

A discussăo que Bakhtin promove entre os gêneros primários e secundários encontra-se em diálogo com a discussăo também feita por ele acerca da vida e da arte, uma vez que, assim como é preciso o estudo da fala cotidiana (da vida) para compreender o enunciado poético (da arte), a compreensáo do gênero primário se faz necessária para o estudo do secundário e vice-versa, uma vez que um se nutre do outro, como dito acerca da cançâo, por exemplo. O gênero secundário surge do primário, da mesma maneira que a arte se nutre, reflete e refrata a vida. Ao mesmo tempo em que se consegue reconhecer a vida na criaçấo de um gênero complexo, torna-se visível a relaçăo dialógica entre a arte e o social - daí, o embate feito pelo Círculo tanto com o formalismo russo quanto com o estruturalismo, expresso pela negaçâo radical do subjetivismo idealista e do objetivismo abstrato, respectivamente (o que se encontra tanto no ensaio "Discurso na vida e discurso na arte", quanto em Marxismo e Filosofia da Linguagem e ainda no Método Formal nos Estudos literários).

Vida e arte, gênero primário e secundário, encontram-se ligados, um em processo de geraçấo do outro (seja de maneira derivada seja em contraposiçăo), em constante relaçăo dialógica. Os gêneros discursivos, conforme discutidos pelos autores do Círculo, sâo reconhecidos ao se aceitar que os diversos campos da atividade (arte, política, ciência, filosofia etc.) têm conexăo intrínseca com a linguagem. Cada esfera, na sua singularidade, necessita da linguagem e essa linguagem tanto altera quanto é modificada, conforme cada discurso e cada gênero específico, pelo ato enunciado. A construçăo de cada discurso utiliza artifícios particulares, pois os enunciados

[...] refletem as condiçōes específicas e as finalidades de cada referido campo năo só por seu conteúdo (temático) e pelo estilo da linguagem, ou seja, pela seleçấo dos recursos lexicais, fraseológicos e gramaticais da língua, mas acima de tudo, por sua construçáo composicional (BAKHTIN, 2011, p. 261).

Por mais que vida e arte estejam interligadas, năo podem ser consideradas a mesma coisa, pois a arte é (re)figuraçăo da vida, e apesar do discurso artístico ter sido construído a partir e por meio do social, sua ligaçăo com ele năo o torna idêntico àquele, uma vez que o representa a partir de determinada(s) voz(es). Na arte, o discurso interpreta a vida, de maneira a dialogar com o social.

O diálogo entre vida e arte deve ser discutido na interaçăo entre gêneros primários e secundários. Na construçăo do discurso artístico, quando em diálogo com a contemporaneidade, encontram-se diversos meios de criaçáo verbo-voco-visual complexa, como no caso aqui estudado, o filme musical. Na produçăo de um filme săo necessárias especificidades de diferentes campos, desde a construçâo de uma breve cena até a arquitetônica da obra genérica. Da micro à macroestrutura săo utilizados recursos 
diversos, como a fotografia, o teatro (a atuaçăo), a escolha do figurino, a movimentaçâo da câmera, a trilha sonora, a iluminaçáo com determinado fim cromático etc. No musical, a especificidade fílmica se encontra na forma composicional da estrutura narrativa, assim como a cançăo denota a sua especificidade genérica, conforme explicitado anteriormente.

\section{AÇÃO: ACROSS THE UNIVERSE ${ }^{104}$}

O filme musical Across the Universe é constituído, em sua trama, apenas por cançôes da banda The Beatles. As cançóes dialogam com o contexto dos músicos, bem como se apresentam ressignificadas, dado o momento histórico de produçâo do filme. Elas se encaixam no discurso dos sujeitos que as interpretam na trama enunciativa, escolhidas para serem entoadas em momentos específicos. A construçáo interativa refigura a vida na arte ao colocar na boca dos sujeitos as letras das cançôes, mas também dialoga as cançôes com as situaçôes vividas pelas personagens no musical e essas situaçôes, na maior parte do tempo, referem-se a episódios históricos ocorridos nos Estados Unidos, nos anos sessentas, especialmente ao que se refere ao cenário contracultural - o movimento hippie, o modo de vida alternativo (de maneira concentrada no Village), o psicodelismo, as produçōes artísticas desenvolvidas na época (em particular duas obras literárias: On the road e Um estranho no ninho), as experiências com drogas (especialmente, LSD, maconha e álcool), as passeatas e movimentos (pacifistas, feministas, etc) e, em especial, a guerra do Vietná.

Nos anos sessentas, muitas foram as expressóes artísticas advindas diretamente do modus vivendi contracultural. Para focar a música e a cançấo, pode-se dizer, com base em Paula (2007), que, por meio do folk e do rock, o público jovem massivo foi cativado. Um público "que começava a fazer desses estilos musicais a expressăo de seu descontentamento e de sua rebeldia, o que flagrou a inseparabilidade da música e da cançâo (ou a arte) com o comportamento" (idem, p. 9).

Conforme Paula (ibidem), conhecido como "verâo do amor", o Festival de Monterey, realizado em Săo Francisco, em 1967, antecipou o Festival de Woodstock, ocorrido em 1969, no estado de Nova Iorque. Muitas pessoas, de diversos estados e de fora do país, mudaram-se para a cidade, invadida por um estilo de vida "paz e amor". Nessa mesma época, os Estados Unidos haviam sido invadidos por ingleses em busca do famoso "sonho americano", dada a crise vivida na Inglaterra e isso também colaborou para o auge da "Nova Inglaterra" (os EUA).

Ainda que Across the Universe narre uma aparente história de amor entre um casal de classes sociais distintas, representantes de dois países diferentes (Lucy, uma garota de classe média alta tradicional norte americana e Jude, um garoto pobre, operário das fábricas inglesas de Liverpool), o filme toca em questóes históricas que văo muito além de uma história de amor. Na verdade, o amor é pretexto para se tocar na história da contracultura norte-americana. As informaçóes quanto a ela aparecem ao longo do filme, de tal forma que o expectador, se năo conhecer a história, pode ter uma leitura que considera apenas a narrativa "happy end" que nâo é, de fato, concretizada, pois o

104 Traduçăo livre de Across the Universe, título do filme e também de uma cançăo de The Beatles: Pelo Mundo. 
filme termina com os dois jovens em dois telhados ${ }^{105}$ de dois prédios de Manhattan, especificamente no Village, local onde moravam os artistas em Nova Iorque, olhando-se de tal forma que leva o expectador a crer que se reencontraram e podem ficar juntos, mas estâo, literalmente, separados. Lucy (referência explícita à cançăo "Lucy in the Sky with Diamond", dos Beatles) năo consegue chegar até Jude ${ }^{106}$ (mais uma vez, o nome da personagem remete ao título de outra cançăo dos Beatles, "Hey, Jude") porque tem sua passagem impedida pela polícia que cerca o prédio em que ele se encontra. Pode-se, entâo, pensar que o casal tem um amor platônico e que cada um representa um país (Jude, a Inglaterra decadente e Lucy, os Estados Unidos) e uma classe social (proletária/operária, o que é visto nas cenas que se passam na Inglaterra - todas, escuras, com predominância do negro, tomadas voltadas às fábricas, bairros operários e esferas trabalhadoras; e média-alta, o que fica nítido logo nas cenas iniciais do filme voltadas aos Estados Unidos - extremamente douradas, ensolaradas e ambientadas em locais abastados), em seu "devido lugar". Se se considerar a cena final do filme, náo há "happy end" e năo se pode pensar que a história por trás da narrativa de amor protagonizada relaciona-se unicamente com uma certa vertente de The Beatles, tamanhas as referências à contracultura, conforme análise de Serni (2013).

Algumas cenas, cores, tomadas cinematográficas, o figurino e até a movimentaçăo das personagens em Across the Universe remetem à história da contracultura norte americana, regada a drogas alucinógenas e psicodelismo, vida alternativa em comunidades, açôes contra a guerra do Vietná e produçôes artísticas (Jude pinta; há um casal de músicos; ${ }^{107}$ a mocinha se engaja no movimento contra a guerra; Max é convocado e obrigado a ir para o Vietná; os protagonistas se mudam para Nova Iorque e vivem em comunidade; algumas personagens sâo referências claras a figuras emblemáticas năo só de Woodstock, mas também de toda a contracultura - como Jimi Hendrix, Janis Joplin e Joe Cocker ${ }^{108}$ - frequentam festas regadas a "refresco elétrico,"109 etc.).

105 Essa cena final refrata o registro da produçáo do último álbum de The Beatles, com clipe filmado no telhado da gravadora da banda. No filme, o primeiro disco de Sadie é gravado no telhado e o emblema da gravadora é o morango pintado por Jude, num ato rebelde, após uma briga com Lucy. Morango/coraçăogranada que também está nos cartazes de divulgaçâo e na capa do DVD do filme. Voltar-se-á à sua representaçăo adiante.

106 Nâo apenas os protagonistas têm os nomes dos sujeitos líricos de cançôes emblemáticas de The Beatles. Outras personagens também encarnam esses papéis, como é o caso de Prudence (de "Dear Prudence"), Max (de "Maxwell"s Silver Hammer"), Sadie (de "Sexy Sadie") e JoJo (de "Get Back"), por exemplo. Contudo, mais que herdar os nomes das personagens das cançôes (muitas vezes, explicitados já nos títulos), os sujeitos fílmicos possuem a sua composiçăo toda calcada nos perfis das personagens beatleneanas. Compreendê-los pede que o expectador adentre o universo tanto da banda britânica (em suas diversas fases) quanto do contexto sociocultural dos anos sessentas.

107 O casal, formado por JoJo e Sadie remetem ao romance lendário de Jimi Hendrix e Janis Joplin. Toda a configuraçâo das personagens (seus perfis, figurino, cançóes, vida alternativa etc) fazem clara referência aos mitos do rock.

108 Joe Cocker, inclusive, aparece no filme e interpreta três personagens diferentes: um cafetăo, um hippie e um mendigo. Com este último papel, toca e canta "Come Together", na rodoviária, como fez em Woodstock, com sua guitarra imaginária (episódio que o deixou conhecido e inspirou muitos roqueiros).

109 Bono Vox, do U2, participa, como Dr. Robert [e faz referência a Timothy Leary, um psicólogo que se torna guru, a princípio, financiado pela CIA para sintetizar o LSD como arma química a ser usada contra a guerra do Vietná e, depois, por defender a tese de que, ao invés de controlar as mentes, o "refresco elétrico", como era denominado ainda em sua fase liberada nos Estados Unidos, muito usado por jovens, especialmente, universitários, poderia expandir a consciência - como acreditava também Aldous Huxley, entre outros artistas da época, conforme Paula (2007), ao se referirem ao LSD e a outros alucinógenos como a mescalina, como o gatilho que abriria "as portas da percepçăo", tese que instigou nomes e filosofias 
Musicalmente, de acordo com Paula (2007), os Festivais reinavam e simbolizavam mais que tocar e ouvir música. Eram movimentos de protesto e vida alternativa (bandeira "paz e amor"). $O$ uso das guitarras era intenso. A exploraçăo do instrumento ocorria de maneira global, de cima a baixo, com escalas que iam dos acordes mais graves aos mais agudos, rasgando o silêncio com distorçâo, flanger, wah-wah e outros efeitos, até a exaustăo das escalas e dos músicos. As letras eram mais "sentimentais", bastante subjetivas, num flerte intenso com a poesia beat. Dois líderes de destaque desse tipo de letra e som sâo Bob Dylan e John Lennon. Aliás, este era uma das figuras que ligava a produçáo de The Beatles com a contracultura norte americana e o mundo pop.

Há muitas referências à contracultura em Across the Universe, ao longo de toda a trama. As citadas aqui săo algumas poucas que, além de refletirem sobre a construçâo do filme musical, demonstram a relaçâo histórica viva semiotizada pelo e no enunciado fílmico, uma vez que toda a sua composiçâo temática e formal está alicerçada na contracultura norte americana. $O$ estilo autoral da diretora Julie Taymor ${ }^{110}$ também é identificado na produçăo fílmica e passa a constituí-la.

Dentre os tantos temas e cançôes explorados em Across the Universe, analisarse-á um dos principais momentos da trama (tanto que uma de suas cenas foi utilizada para a divulgaçấo do filme, como capa do DVD e imagem dos cartazes comerciais da obra): a execuçấo da cançăo "Strawberry Fields",111 símbolo da ferida emocional vivida por Jude e Lucy, na relaçâo amorosa em si, e, principalmente, como morango/ coraçấo-bomba que se refere à dor do casal pela separaçấo deles de Max, irmáo de

continua 109

de bandas como The Doors, por exemplo - foi banido de Harward, onde lecionava, e perseguido pelo mesmo Governo que antes incentivara e encomendara sua pesquisa inicial. Nesse momento é que o uso da droga foi proibido]. Bono (Dr. Robert - alusâo a Ken Kesey, autor de Um estranho no ninho) aparece numa festa em que Lucy e seus amigos experimentam o "refresco elétrico" e toda uma sequência de cenas representam o estado alucinógeno vivido pelas personagens (cores fortes etc), o que remete ao psicodelismo. A cançấo que embala esse momento do filme, cantada pela personagem interpretada por Bono é "I am the Walrus", com uma letra aparentemente sem conexáo entre seus versos, numa narrativa solta que aproxima elementos de convivência aparentemente desconexas.

110 Talvez, o filme mais conhecido dirigido por Taymor seja Frida. Mas, ela é conhecida pela produçáo de musicais e óperas, tanto para cinema quanto para teatro. Alguns de seus trabalhos săo a versăo de Rei Leâo para o teatro, Spider-Man: turn off the dark e a versấo off-broadway de Sonho de uma noite de verâo. Dentre as características que compóem o seu estilo, reconhecíveis em Across the Universe, destacam-se a intensidade e a performance. A tentativa é a de se fazer uma ópera pop, com elementos que fundem estratégias do teatro (tais como a utilizaçăo de bonecos gigantes, máscaras, objetos performáticos, entre outras) e do cinema (tudo gira em torno da cançăo, ora coreografada ora năo; as tomadas da câmera em ângulos típicos de um espetáculo, com os atores voltados para o público, tanto em tomadas internas quanto externas). A iluminaçăo é sofisticada, com papel de destaque. 0 figurino e a cenografia são ricos em detalhes, reconstroem a época e ambientam as personagens, assim como a conglomeraçăo de múltiplos núcleos narrativos que se encontram e podem ser analisados em conjunto, na constituiçâo da arquitetônica enunciativa; ou isoladamente, uma vez que cada personagem ou grupo de personagens possui uma célula dramática desenvolvida (alguns exemplos sáo Jojo e Sadie, voltados à construçấo mais estável de suas carreiras e de seu relacionamento amoroso; Prudence e o dilema com sua homossexualidade; Jude e a busca de sentido para a sua existência; Lucy e o engajamento pela família, contra a guerra, pelo feminismo e pela liberdade sexual; Max e sua tentativa frustrada de resistência e fuga do sistema).

111 A sequência fílmica encontra-se disponível em 〈https://www.youtube.com/watch?v=htxOSyWON2k〉 (Acesso em: 30 de março de 2015). Strawberry Fields se encontra no álbum Magical Mystery Tour, de 1967. Este álbum, depois de Sgt Pepper's Lonely Hearts Club Band, representa o auge da psicodelia do grupo. A banda deixa o rock "iê-iê-iê" para mergulhar na contracultura, por meio de cançóes psicodélicas, mensagens de paz e amor, contra a violência e a guerra. Os discos de 67 e 68 marcam a sua fase "Revolver" e "pós-revolver", encaminhada ao rock progressivo que, para alguns, é a grandeza da banda, sua fase "madura" musicalmente, com estruturas e execuçôes complexas. 
Lucy e melhor amigo de Jude, convocado pelo exército (por meio da cançăo "I want you", 112 cantada pelo Tio Sam) para ir à guerra "proteger o país".

A capa que se segue, do DVD na sua versâo brasileira, é a mesma do cartaz e coincide com a abertura do filme: o céu estrelado que remete a "Lucy in the Sky with Diamonds", com uma mancha vermelha ao centro que contem Lucy e Jude se olhando, uma macha verde acima e um formato que funde um morango a um coraçăo e a uma granada, o que se refere tanto ao amor dos protagonistas quanto à guerra do Vietnâ. O morango que se encontra no centro da imagem (capa, cartaz e cena) será, no filme, logotipo da gravadora de Sadie, desenhado por Jude. Esse logotipo representa a voz contracultural alternativa das personagens do filme. Uma crítica à guerra e um pedido de paz e amor a todos, o que se revela pela explosáo de amor entre Lucy e Jude, de Lucy e Jude por Max e pela explosâo de bombas e granadas no Vietnă, uma vez que cenas desses dois universos (o amor e a guerra) se sobrepóem, especialmente na cena em que a cançăo "Strawberry Fields"113 é interpretada (conforme será analisado a seguir):

112 Há diversos deslocamentos e construçôes de sentidos variados no ato de execuçăo de "I want you" no filme, a depender de cada situaçấo vivida por cada personagem que a entoa. Se, para Max, o dilema vivido é ter que ir à guerra e a cançâo é cantada pelo Tio Sam, com soldados em marcha a rotular a personagem, contra a sua vontade, com tom convocatório e militar; para Prudence, apaixonada por Sadie, cantar "I want you" num tom rouco, com andamento musical lento, quase que como uma confissăo, do lado de fora da casa, no telhado, olhando o casal da janela do banheiro, possui um tom amoroso doloroso. Essa mesma cançấo, entoada por Sadie, dentro de casa, namorando JoJo e levando-o pela mấo para o quarto, tem um tom amoroso sexy, bastante diferente daquele sofrido cantado por Prudence. O mesmo enunciado, portanto, ambientado de maneiras diferentes e colocado como voz de personagens específicas adquire significaçôes próprias, nem sempre relacionadas à entoaçâo da cançāo apartada da trama fílmica. Com esse exemplo, pode-se ver o quanto a canção, mais que incorporada, passa a fazer parte da constituiçăo genérica do filme, muitas vezes, inclusive, adquirindo construçóes de sentidos próprias à situaçầo narrada/entoada. Além disso, as diferentes significaçôes dessa cançâo demonstram o quanto o enunciado é único.

113 A letra de "Strawberry Fields" ("Campos de Morango"): "Let me take you down / "Cause I"m going to Strawberry Fields / Nothing is real and nothing to get hung about / Strawberry Fields forever //Living is easy with eyes closed / Misunderstanding all you see /It"s getting hard to be someone / But it all works out / It doesn"t matter much to me // Let me take you down / "Cause I"m going to Strawberry Fields / Nothing is real and nothing to get hung about / Strawberry Fields forever // Always, no, sometimes, think it"s me / But you know I know when it"s a dream / I think, er, no I mean, er, yes / But it"s all so wrong / That is I think I disagree // Let me take you down / "Cause I"m going to Strawberry Fields / Nothing is real and nothing to get hung about / Strawberry Fields forever / Strawberry Fields forever / Strawberry Fields forever". Traduçâo livre das autoras: "Deixe-me te levar / Pois estou indo aos campos de morango / Nada é real e nâo há nada com o que se preocupar / Campos de morango para sempre //Viver de olhos fechados é fácil / Entendendo mal tudo o que você vê / Está ficando difícil ser alguém / Mas tudo se ajeita / Nâo importa muito isso pra mim // Deixe-me te levar / Pois estou indo aos campos de morango / Nada é real e nấo há nada com o que se preocupar / Campos de morango pra sempre //Sempre, năo, às vezes, pense que sou eu /Mas você sabe que eu sei quando é um sonho / Eu acho, năo, digo, sim / Mas está tudo tăo errado / Isso é, acho que discordo // Deixeme te levar / Pois estou indo aos campos de morango / Nada é real e náo há nada com o que se preocupar Campos de morango pra sempre / Campos de morango pra sempre / Campos de morango pra sempre". 


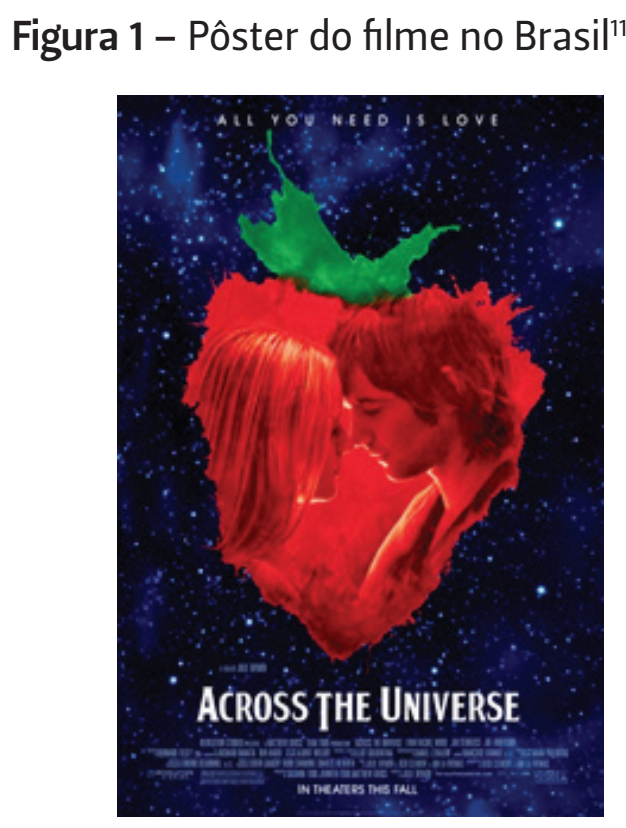

Fonte: Quero Posters

O morango e o "universo" por trás da imagem săo significativos para a constituiçăo temática do musical, pois a cançâo Strawberry Fields ilustra os sentimentos das personagens, tanto ao que se refere ao amor quanto à guerra. O desenho dos protagonistas dentro do morango/coraçấo-granada direciona o olhar do leitor para uma história de amor que é pretexto para outra história ali existente: a da contracultura, "paz e amor", embalada pelo rock e pelo LSD (os diamantes estrelares do céu que pairam como pano de fundo do cartaz) em contraposiçáo às revoluçóes e às guerras existentes. Ao mesmo em que o morango pode simbolizar o amor, também representa o sangue da guerra e as bombas jogadas em território "inimigo" pelo governo dos Estados Unidos. O que significa atravessar o Universo e a que universo se refere o mundo do rock beatleneano do filme, de maneira musical? Pelas pesquisas realizadas, atravessar o universo significa andar pelo mundo geográfica e internamente, política e sensorialmente, como pregava o movimento contracultural da época, como se pode visualizar pelos fotogramas (figuras 2 a 5) que seguem, de cenas apresentadas no momento da execuçâo da cançâo por Jude, que espeta os coraçóes enfileirados, em seu quadro, numa alusăo à concepçáo de que o sofrimento amoroso vivido pode ser utilizado como matéria artística numa relaçấo explícita entre a vida elaborada esteticamente pela arte:

Legenda 1: Cena do filme em que Jude canta Strawberry Fields após ter discutido com Lucy, enquanto observa o quadro dos morangos espetados que acabara de criar, feridos, escorrendo sangue, como soldados enfileirados.

114 Fonte: Quero Posters. Disponível em: <http://www.queroposters.com.br/poster-across-the-universe. html. Acesso em: 7 fev. 2014. 
Legenda 1: Cena do filme em que Jude canta Strawberry Fields após ter discutido com Lucy, enquanto observa o quadro dos morangos espetados que acabara de criar, feridos, escorrendo sangue, como soldados enfileirados.

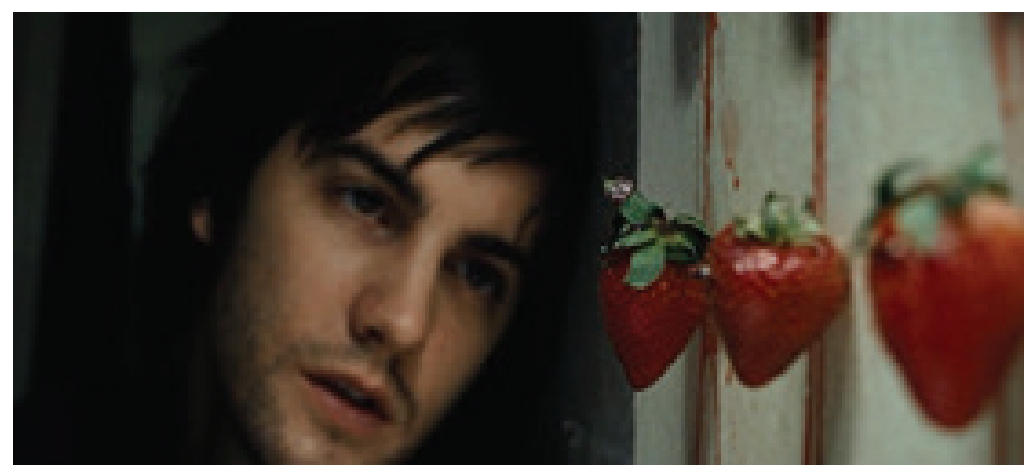

Fonte: Across the Universe (2007)

Legenda 2: Enquanto Jude canta, imagens de sangue, morte e bombas remetem ao Vietnă e se fundem com o quarto onde o protagonista cria. A granada prestes a explodir se torna o coraçấo esmagado na mâo da América e de Lucy.
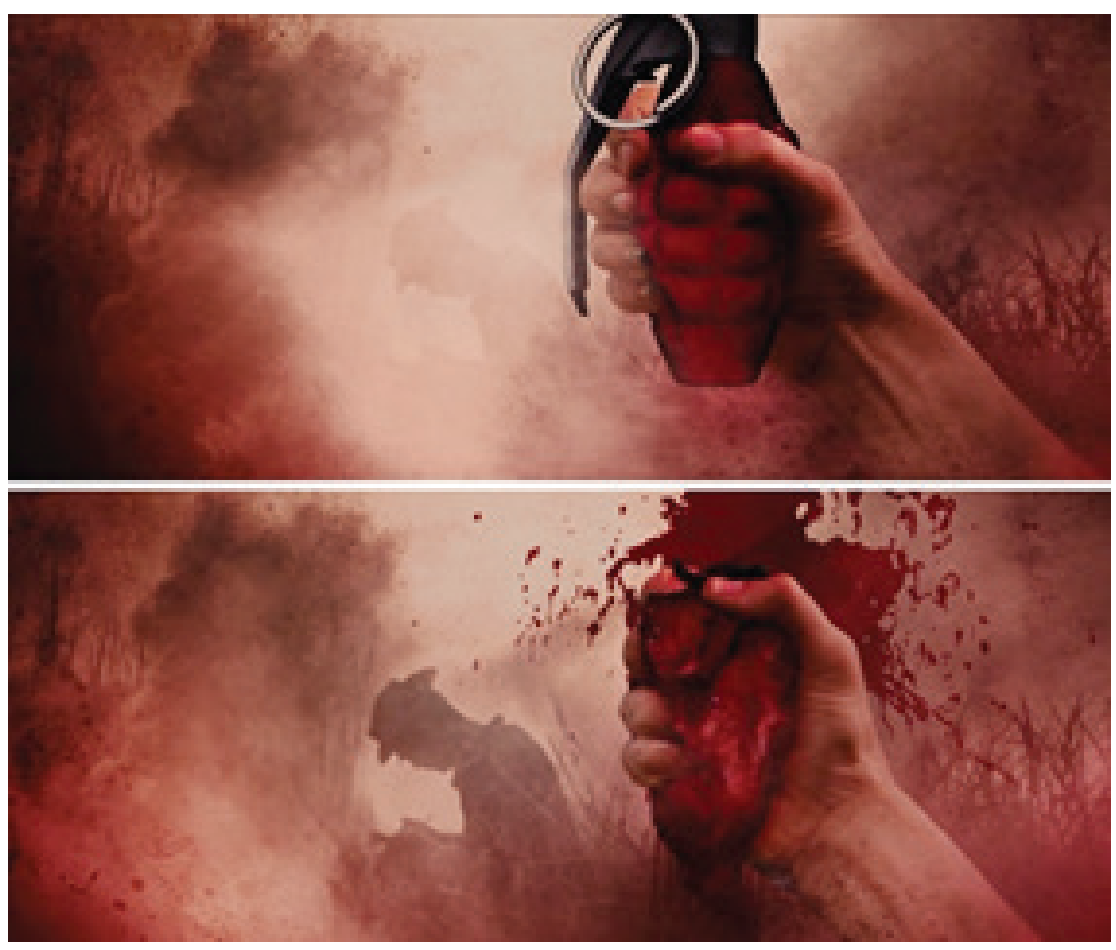

Fonte: Across the Universe (2007) 
Legenda 3: Jude, em explosăo de ciúme de Lucy e revolta pela guerra. A explosâo das granadas e da morte săo matéria-prima para a explosáo de cores a tinta representando o sangue que tinge o amor e o morango que simboliza o coraçáo partido também explode em forma de arte, no quadro que compóe.

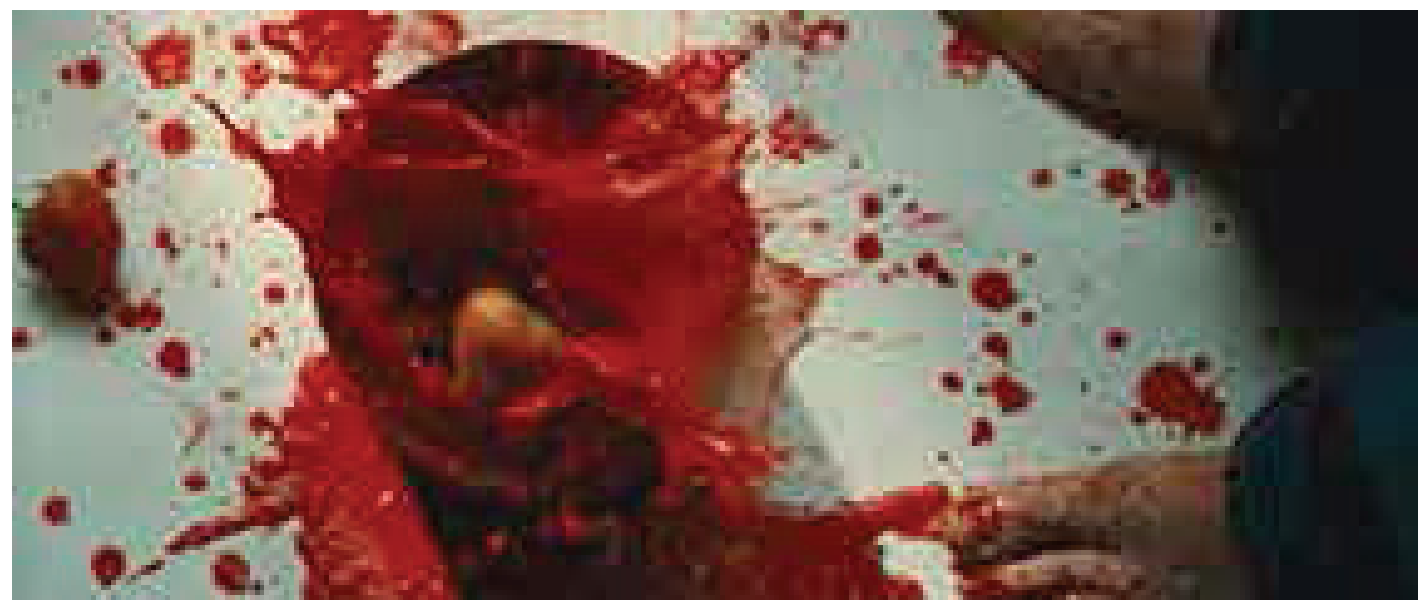

Fonte: Across the Universe (2007)

Legenda 4: Enquanto Jude "suja" todo o quarto com tinta/sangue para compor sua obra, a câmera se afasta, o chăo do quarto desaparece e os morangos caem como bombas sobre um território náo identificado, mas com referências ao Vietná. Nesse momento, surgem sons de queda (assobio) e explosōes (bateria e inclusâo incidental de som de bombas e tiros de metralhadora) no fundo da cançáo entoada por Jude. Tudo se funde: imagens, sons e sentimentos, num grande "caos" "Across the Universe" ("através do universo").

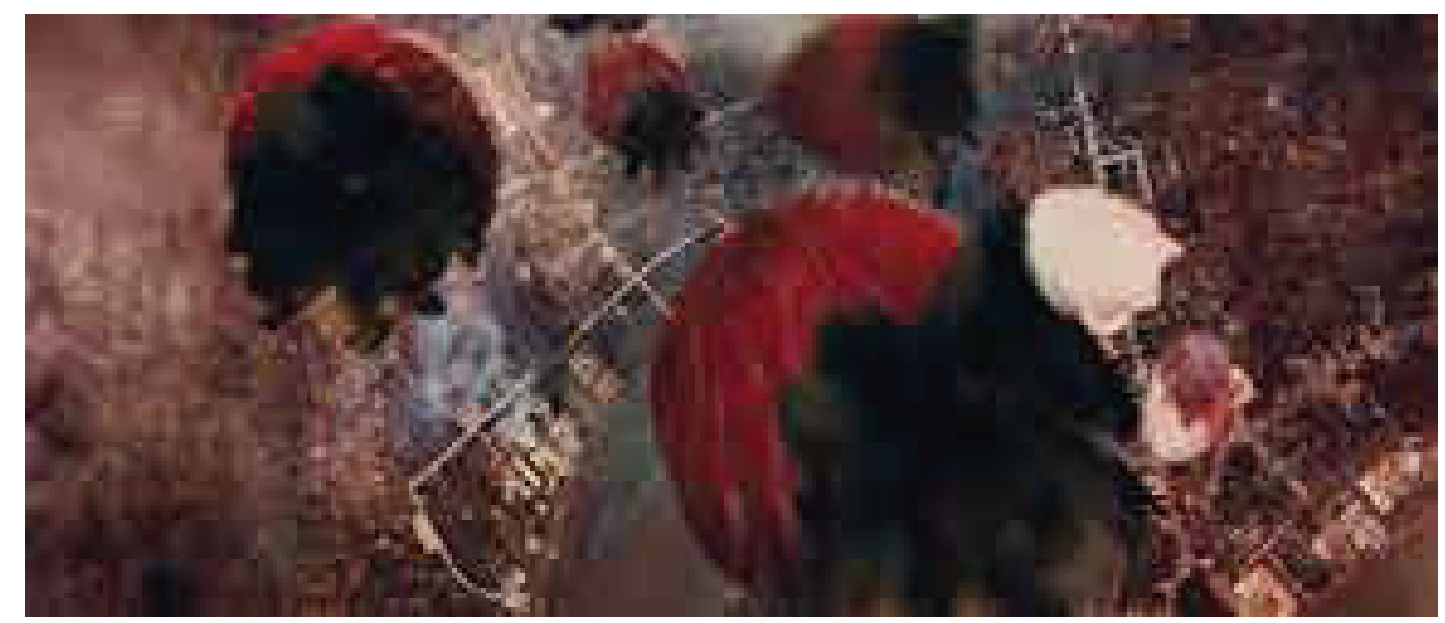

Fonte: Across the Universe (2007) 
A crescente independência de Lucy e seu engajamento político incomodam Jude, que năo se interessa pelos mesmos ideais e năo aceita que a parceira trabalhe e se torne independente. Sua revolta com essa situaçăo transparece na cançăo "Strawberry Fields" e também em "Revolution". Jude chega a invadir o trabalho de Lucy e lá entoa a letra de "Revolution": "You say you want a revolution / well you know / we all want to change the world ${ }^{115 "}$ e, ao mesmo tempo em que canta, ele se revolta, atirando papéis para cima e bagunçando o local, até ser expulso. A revolta de Jude se dá por conta de Lucy assumir o comando de sua vida ao trabalhar fora e participar ativamente do movimento pacifista contra a guerra, por isso ele fica "em crise", com ciúmes de Lucy com o líder pacifista e interpreta Strawberry Fields. Esses momentos (de Revolution e de Strawberry Field) marcam também o embate de gêneros tăo característico dos anos sessentas, pois a revoluçâo desejada năo é apenas contra a guerra do Vietnă, mas também a revolução feminista e a sexual.

Enquanto Jude canta em seu apartamento, depois de fumar um cigarro de maconha (Figura 6), embalado pela voz dos jornalistas vinda da televisăo na sala ao lado, Max também interpreta a cançăo no campo de batalha e as imagens dos dois aparecem sobrepostas invertendo os lugares de cada personagem - Max no quarto com Jude e Jude na guerra com Max (Figuras 7 e 8). Ao mesmo tempo, Lucy vê as notícias sobre a guerra pela TV e, preocupada com o irmăo, projeta-o nas imagens dos soldados transmitidas pelos noticiários e também há a sobreposiçấo de imagens da guerra com Lucy (Figuras 9 e 10).

\section{Legenda 5: 0 cigarro de maconha como disparo para a inspiração criativa como típico elemento contracultural.}

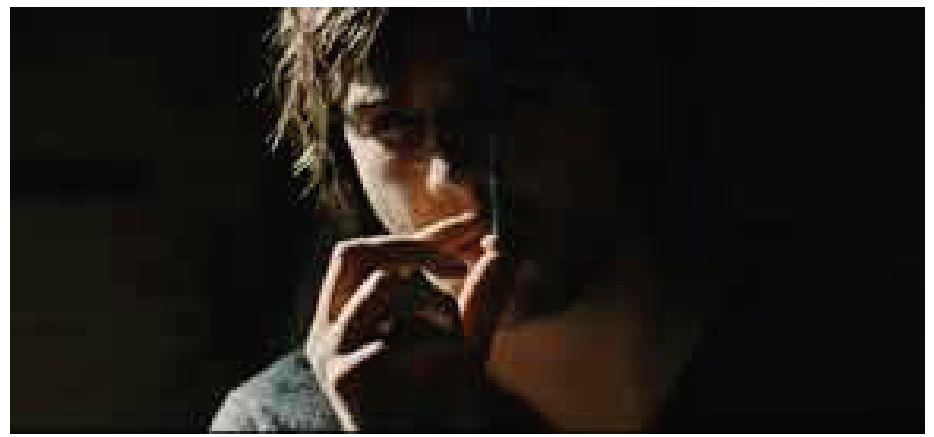

Fonte: Across the Universe (2007)

Legendas 6 e 7: Jude e Max sobrepostos e unidos pelo pensamento, um no lugar do outro.
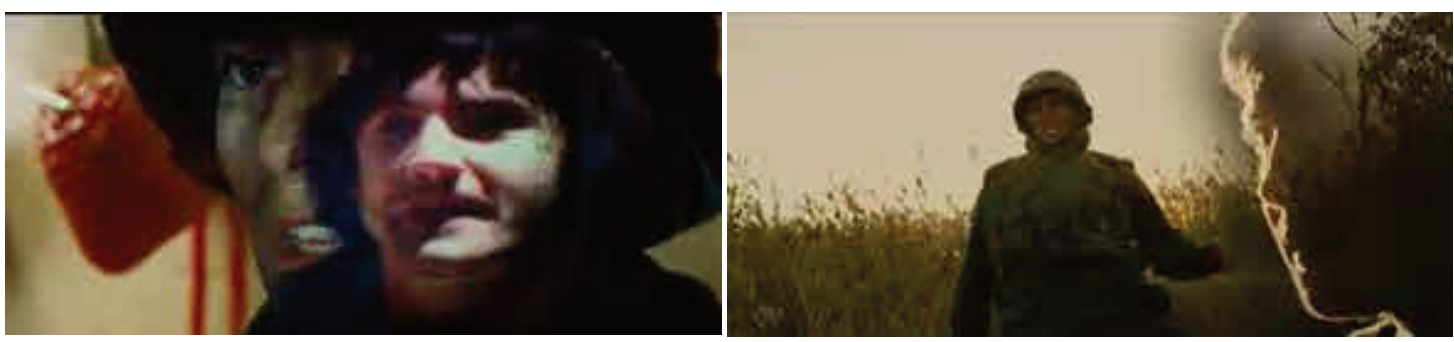

Fonte: Across the Universe (2007)

115 Traduçáo livre do trecho da cançăo "Revolution" ("Revoluçâo") feita pelas autoras: "Você diz que quer uma revoluçăo / bem, você sabe / nós todos queremos mudar o mundo". 
Legendas 8 e 9: Lucy assistindo a transmissão da guerra pela TV, imaginando ver seu irmão e as imagens de soldados armados na guerra sobrepostas, em sua face e mente.
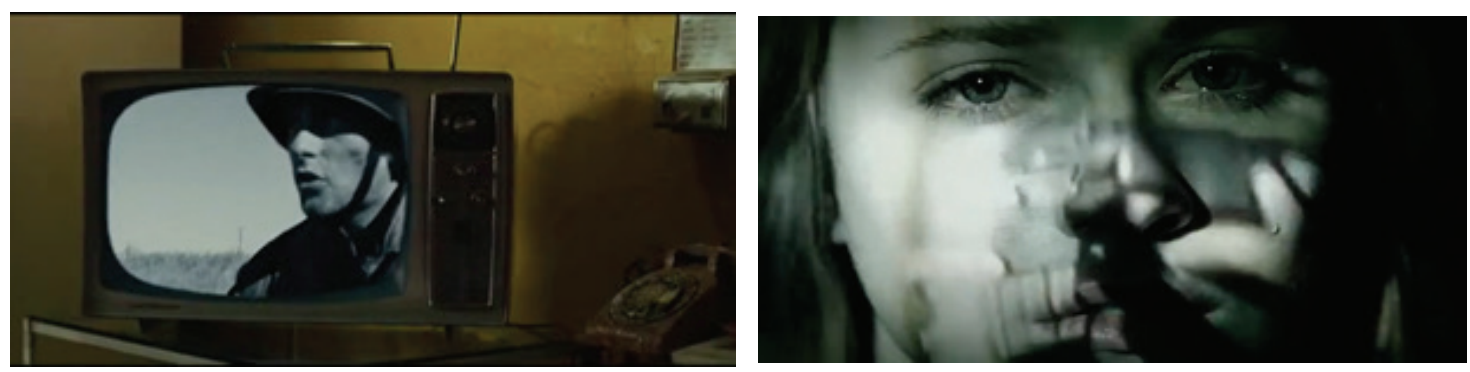

Os "Campos de Morango", título da cançāo (consagrados na história de vida de John Lennon, por remeterem à sua infância), ${ }^{116}$ fazem referência, neste momento do filme, à dor sentimental de Jude (que sente ciúmes de Lucy) e à dor dos soldados, que servem ao exército na guerra, como Max, involuntariamente, obrigados pelo governo norte-americano. Os morangos que Jude joga na tinta vermelha e espeta num quadro săo jogados também sobre o campo de batalha e se tornam bombas, numa sequência cênica que traz imagens históricas (registros reais) de explosóes de bombas em tempo de guerra, transmitidas pela televisăo.

Os morangos, como coraçóes enfileirados, espetados como soldados atentos (mortos-vivos desde a sua convocaçăo), com sangue escorrendo de seus corpos (muitos mortos, de fato, na guerra ou com o psicológico afetado quando voltavam para a casa), representam, no filme, que universo(s)? Vivos, disformes como săo compostos, eles remetem ao universo contracultural que clama "paz e amor" e da cultura pop de Andy Warhol (com sua crítica à homogeneidade que reifica o homem exatamente ao colocar lado a lado, reproduzidas, imagens - como a de Marilyn Monroe, a de uma embalagem de sopa e a da lata de Coca-Cola - iguais, com cores vibrantes diferentes para questionar o que faz o capitalismo com as pessoas), do rock (dos The Beatles) e dos hippies em oposiçăo ao universo hegemônico capital vigente (representado pelas figuras do Tio Sam e da estátua da liberdade, no filme, embalados pela cançấo I want you - que, nos anos sessentas ficou muito conhecida pela voz de Bob Dylan, um dos ícones da contracultura, por suas cançôes de protesto); e dos Estados Unidos (e seu slogan American way of life) com a Inglaterra e o Vietná.

A cançăo é entoada por Jude depois de Lucy chegar em casa com o líder do movimento pacifista no qual se encontra engajada, com uma televisăo para assistir à transmissáo da guerra. Jude se encontra tentando criar um quadro para ser a logotipo da gravadora de Sadie. Como Cézanne, ele tenta fazer uma obra de natureza morta, a partir da reproduçâo, com carvăo, o mais "fiel" possível, de frutas como maçă verde, pera, banana e morangos. Lucy estranha, pois o estilo de Cézanne nada tem a ver com

116 John Lennon disse, em entrevista, que compôs Strawberry Fields ao se lembrar de sua inocência na infância, pois saia para brincar num campo de morango pregado a um campo de concentraçáo nazista, sem se dar conta do que significava aquele campo tấo belo, suculento e alegre junto do sangue preconceituoso derramado no campo ao lado. Assim, essa relaçáo entre o amor pueril e a guerra, explicitada no filme, de certa forma, também remete à constituiçăo da cançấo, conforme a fala de seu autor-criador. Tanto a cançấo quanto o filme (a arte) se nutrem e refiguram a vida. 
a poeticidade de Jude, com Sadie e com o momento vivido. Irritado, ele pega o prato de frutas e se fecha num outro cômodo da casa. Fuma um baseado e começa a entoar Strawberry Fields. Confuso, Jude (re)produz, como , à maneira de Warhol, um quadro de morangos enfileirados. Só, depois, com a explosăo dos morangos e de sua revelaçấo emotivo-volitiva, consegue, finalmente, criar um quadro seu, reconhecido pela gravadora e é, inclusive, pago por sua arte (que agrada ao capital, ainda que seja crítica e questionadora).

A matéria prima (saída da vida) para a criaçâo artística pode ser qualquer uma (no caso, frutas). A questăo é o tom emotivo-volitivo, elaborado esteticamente. A maçấ, reproduzida de forma clássica, como natureza morta, revela um posicionamento axiológico bastante distinto dos morangos espetados na tela, como pop art e do morango/ coraçăo-granada criado por Jude. No primeiro caso, a voz de Jude encontra-se "morta", artificial; no segundo, a sua indignaçâo ainda năo tem um estilo próprio; apenas na terceira explode, em grito entoativo, o seu estilo autoral. O morango-coraçăo-granada revela, de forma elaborada esteticamente (como arte), a dor do ciúme da namorada e da falta do amigo, levado pela guerra (situaçăo vivida). Os morangos-coraçōes-granadas dilaceram Jude tanto quanto os vietnamitas e os soldados norte-americanos na guerra.

Strawberry Fields é emblemática e, de certa forma, simboliza a temática do filme porque sua letra se volta à alienaçấo (Living is easy with eyes closed - "Viver com os olhos fechados é fácil"), à relaçâo realidade e sonho (Cause I"m going to Strawberry Fields / Nothing is real and nothing to get hung about - Pois estou indo aos campos de morango / Nada é real e năo há nada com o que se preocupar; But you know I know when it"s a dream - Mas você sabe que eu sei quando é um sonho"), ao questionamento e à crítica ao momento vivido (But it"s all so wrong - Mas está tudo tăo errado) e, principalmente, ao drama vivido por Jude quanto à sua identidade artística e a uma "causa" (um ideal) pelo qual lutar e ver sentido na vida (It's getting hard to be someone - "Está ficando difícil ser alguém") e a sua perdiçăo (I think, er, no I mean, er, yes / But it"s all so wrong /That is I think I disagree - Eu acho, nâo, digo, sim / Mas está tudo tâo errado / Isso é, acho que discordo"). Diante de tantas indecisōes e indagaçôes, uma certeza existe: mudar o sistema e acabar com o campo de concentraçấo que se tornou o mundo, transformando-o num campo de morango para sempre (Let me take you down - Deixe-me te levar; e, finalmente, Strawberry Fields forever - Campos de morango para sempre). Nesse sentido, os campos de morango representam a fuga sistêmica, uma espécie de "mundo das maravilhas" ideal contracultural. Todavia, impossível esquecer que até mesmo no mundo das maravilhas há enfrentamentos com rainhas e bruxas. Se, por um lado, o tom é desesperançoso (sem saída, sem sonho, sem identidade, sem ideal), por outro, é questionador, pois a transformaçăo é clamada como abertura dos olhos, que deve explodir, interna e externamente, como granada nas mentes e nos coraçóes despreparados. Isso é exatamente o que ocorre com Lucy e Jude.

No caso de Jude, ele começa sem inspiraçăo, imitando Cézanne, ao rascunhar uma obra de natureza morta (figura 11); passa à reprodutibilidade da pop art de Andy Warhol (figura 12); para, finalmente, encontrar sua revoluçáo quando se expande e se mostra, de forma passional, em seu novo quadro (figura 13). Enquanto pinta, cenas da guerra do Vietná passam pela televisăo, na sala, dentro de sua mente e imagens do filme sâo entremeadas por imagens reais da época. 
Figura 2 - Rascunho de natureza morta, como Cézanne

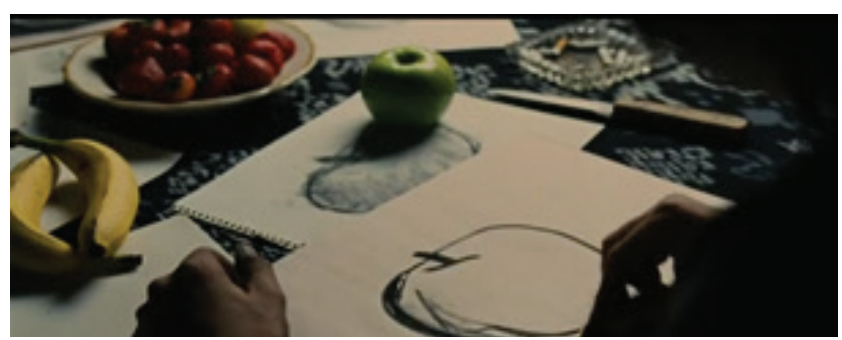

Fonte: Across the Universe (2007)

Figura 3 - Quadro de pop art, no estilo de Andy Warhol

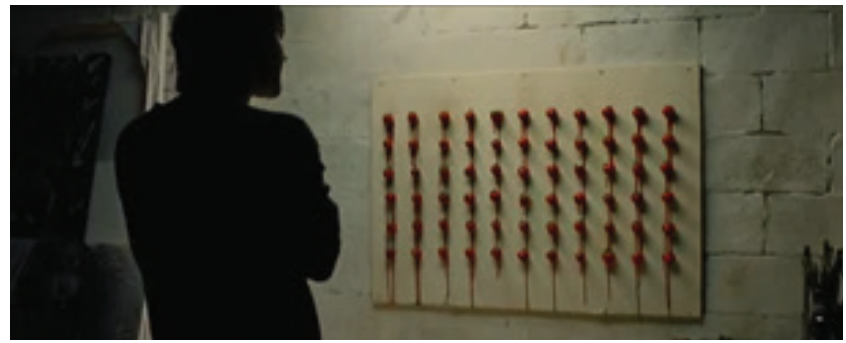

Fonte: Across the Universe (2007)

Figura 4 - Quadro definitivo de Jude que se transforma no logotipo da gravadora de Sadie e símbolo do filme

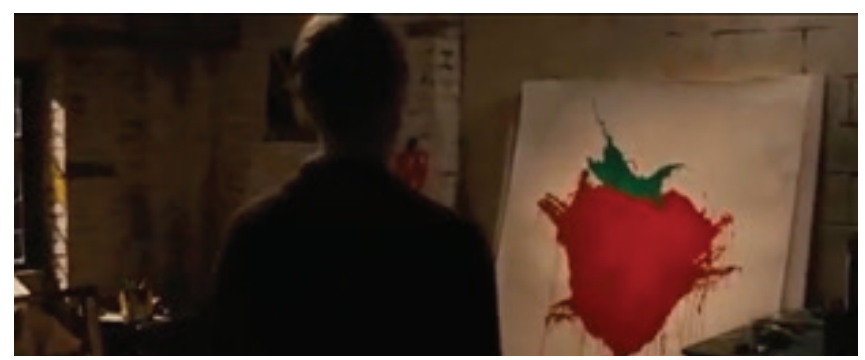

Fonte: Across the Universe (2007)

A figura abaixo, recorte da quarta capa do DVD, apresenta o filme como uma obra que se volta a uma história nâo hegemônica por meio de cançōes de , típicas da memória musical e cultural da sociedade, inseridas numa narrativa específica, que reflete e refrata valores dos anos sessentas, colocadas de uma maneira particular, com um posicionamento axiológico específico: 


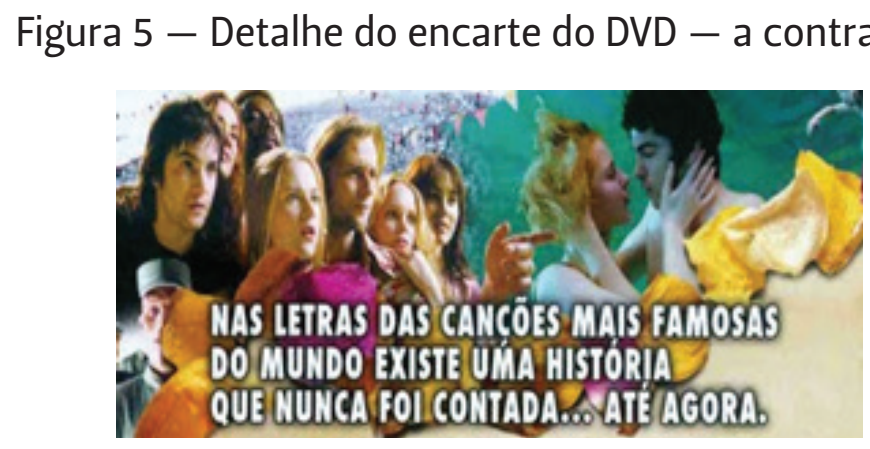

Fonte: Capa do DVD de Across the Universe (2007)

Se o morango, na capa e no cartaz, ao formar um coraçăo em torno do casal protagonista do filme, constrói o sentido de que o morango simboliza o romance; essa mesma fruta, na interpretaçăo de Strawberry Fields, mostra-se vermelho sangue, bombástico, violento, ou seja, semiose das diversas guerras vividas: a briga amorosa do casal, a separaçấo da família e dos amigos pela guerra, a destruiçăo de países pela disputa político-econômica desumana entre naçôes. A entoaçăo da cançăo assegura o tom raivoso dos gestos e das cenas imageticamente compostas no filme, pois Jude performatiza a cançấo com gestos coléricos ao pintar seu quadro, ambientado pelo som da TV que transmite a guerra do Vietná (com sonoplastia de bombas e tiros, assim como por vozes de jornalistas), pelo ciúme exacerbado, pela falta de inspiraçăo e pela falta do amigo, que se encontra na guerra. Mais que ambientar a trama, a cançâo é a voz da personagem, externalizada tanto pelo verbal (a letra da cançâo e a fala dos jornalistas na TV) quanto pelo năo-verbal (música, sonoplastias e imagens), assim como representa o posicionamento da diretora (sua voz criadora autoral) e ainda semiotiza a história (a contracultura nos anos sessentas) ao encarnar a vida na arte.

Ao término da execuçăo de "Strawberry Fields", a câmera sai das cenas do quarto e da mente de Jude e Lucy desfocada e se distancia, tornando nítida uma máquina de lavar roupa, numa lavanderia, com roupas brancas sendo lavadas. A sujeira do sangue e da guerra alvejada pela máquina, num aparente discurso de paz. Aparente porque, em outro momento do filme, o líder do movimento pacifista aparece confeccionando bombas caseiras para serem usadas nas passeatas antiviolência. Lucy o indaga acerca dessa contradiçấo (diz: "Eu pensei que o outro lado é que atirava bombas") e vai embora. A próxima cena, depois da discussăo entre o casal e a sujeira feita por Jude no quarto para produzir o seu quadro, ocorrer numa lavanderia também representa a "lavagem de roupa suja" da relaçâo do casal (que, a seguir, separa-se).

Uma marca deste filme que náo é típica do gênero filme musical, mas é muito expressiva em Across the Universe é a incorporaçâo de pinturas, de diversos estilos, na composiçâo da obra, seja por interdiscursividade seja por intertextualidade. Além da criaçăo de Jude, que poderia nem ser considerada por se tratar da profissăo da personagem, outro exemplo ocorre na cena de execuçâo de "Dear Prudence", em que as paredes da sala da casa comunitária onde todos moram no Village se transformam num céu repleto de nuvem, como um quadro de Magritte. A cena em que executivos andam de maneira coreografada pelas ruas também parece outro quadro de Magritte em movimento. Esses săo apenas alguns dentre os vários exemplos. 
Ao que se refere às execuçōes das cançôes, neste filme, elas também possuem uma peculiaridade: muitas vezes, elas sâo realizadas a capela ou embaladas com um único instrumento de fundo. Essa năo é uma característica comum do gênero, mas sim deste enunciado. Em geral, as cançóes entoadas a capela ocorrem em momentos em que as personagens falam sobre seus dilemas internos, sem coreografia, como se externalizassem seus sentimentos ou pensamentos.

Tanto a exemplificaçăo da incorporaçăo de outro gênero (a pintura) pelo gênero fílmico quanto a da execuçáo à capela e sem coreografia foram citados para demonstrar o quanto a reles incorporaçấo de um gênero por outro nâo denota intergenericidade e variaçáo ou mudança na constituiçáo genérica. Ao mesmo tempo, especialmente a execuçăo da cançăo realizada de uma maneira específica revela a relativa estabilidade do gênero. Afinal, se, por um lado, identificamos, pela cançáo, que o filme faz parte da arquitetura do gênero musical, por outro, ele inova o gênero ao utilizar a cançâo de uma maneira única, năo peculiar à tradiçâo clássica do gênero.

Os trechos aqui explicitados apenas ilustram muito brevemente o caráter intergenérico do gênero filme musical. Conforme dito, nos estudos de Bakhtin, os gêneros discursivos săo compreendidos como relativamente estáveis, pois se encontram em movimento, ou seja, nâo existe gênero acabado, fechado, cristalizado, mas em processo de acabamento, com recorrências e também possibilidades de variaçăo. Esse é o caso ilustrado por Across the Universe. A exemplificaçăo năo busca finalizar um acabamento para este gênero, mas, demonstrar a representaçăo da vida pela arte por meio de um exemplo de gênero específico, o filme musical, com suas características típicas e particulares, especialmente ao que se refere ao estilo da autora-criadora (tomada como a diretora da obra) e, principalmente, à arquitetura composicional do enunciado mencionado, tanto de regularidade quanto de variaçâo genérica.

\section{CONSIDERAÇÕES FINAIS}

A vida, seja no pequeno (cotidiano) ou no grande tempo (histórico), é refigurada pela arte, que lhe dá acabamento estético específico a depender da arquitetônica do gênero que a concretiza. $O$ ato responsivo de reconhecimento das particularidades da composiçáo de cada gênero é realizado, na arte ou na vida, pelos sujeitos discursivos que, na perspectiva bakhtiniana, constituem-se na relaçâo eu-para-mim, eu-para-o -outro, outro-para-mim, interna e externamente.

Năo apenas o filme, mas os gêneros discursivos em geral devem ser pensados em suas regularidades e singularidades (isto é, em sua relativa estabilidade), de maneira interativa. Nâo basta olhar o conteúdo, a forma e o estilo, mas também as esferas de atividade nas quais sâo produzidos, circulam e sâo recebidos (tendo em vista a recepçâo ativa, uma vez que, nela, os sujeitos respondem com novas produçôes - na contemporaneidade, isso fica claro se se considerar năo só as discussôes sobre um dado enunciado, sempre genérico, mas também as produçóes realizadas a partir desse enunciado, em resposta a ele e, a depender do caso, alterando-o, como ocorre, por exemplo, com fanfics, fanarts e sua relaçáo com o seriado televisivo).

Ao se pensar sobre um determinado gênero, deve-se contextualizá-lo, pois as referências históricas, culturais e sociais, de determinado(s) ponto(s) de vista, adentram os 
enunciados (nunca neutros) por meio da(s) voz(es) social(is) assumidas e/ou negadas dos sujeitos discursivos (autor-criador, narrador - no caso do filme, essa funçấo é assumida pela câmera - personagens). Assim, a valoraçấo à contracultura em Across the Universe, por exemplo, compóe a temática, a forma e o estilo do filme, assim como revela o posicionamento axiológico da autora-criadora (a diretora), orquestrado esteticamente no filme pela composiçăo das personagens, da cenografia, pela escolha das cançôes, a tomada da câmera, o figurino, as estratégias utilizadas para marcar a sua voz por meio do estilo assumido etc. Esse conjunto de fatores, ao mesmo tempo, identifica Across the Universe como gênero filme musical e constrói a sua peculiaridade enunciativa que, de certa forma, constitui-se como variaçấo dentro do próprio gênero.

O fato de as cançôes serem entoadas à capela, de forma confessional ou com sonoplastias e a música mais baixa que a letra, como fala das personagens, sem coreografia, enquanto os sujeitos atuam, por exemplo, criando um quadro, como ocorre em "Strawberry Fields" e em tantos outros momentos da obra, ilustra essa caracterizaçăo relativamente estável do gênero filme musical.

A variaçăo se dá pelo estilo e pode se tratar apenas de uma peculiaridade de determinado enunciado (o estilo de dado autor-criador), assim como pode levar a um novo caminho que pode, com o tempo, alterar o gênero (pode ser que outros filmes utilizem a mesma "técnica" e, se isso passar a ser recorrente, talvez, no grande tempo, a coreografia possa náo ser mais o foco dos musicais). Apenas a recorrência desse traço em diversas obras pode designar se o gênero será alterado ou năo. Desse ponto de vista, a variaçăo se dá no embate com a regularidade. A instabilidade só é possível dentro da estabilidade, daí, a relatividade se encontrar no embate que năo despreza nenhum ponto de vista, assim como năo opta por este ou por aquele polo. A questăo năo se encontra na exclusấo dicotômica, mas sim na igualdade e na diferença dentro do enunciado, colocadas ao mesmo tempo, de maneira viva, em embate, no jogo discursivo, que reflete e refrata a vida - na arte, com elaboraçăo e acabamento estético.

Năo se pode esquecer que o gênero fílmico é massivo e atende a determinadas demandas (tais como a popularidade, o consumo capital, entre outras), mas isso năo exclui a sua riqueza estética, da mesma maneira que náo se pode tratá-lo como enunciado artístico náo comercial (e, no mundo capital, a arte, mesmo a năo-massiva, pode ser/ estar apartada do mundo e dos interesses de consumo? Com base no Círculo, năo. Afinal, a arte é, como todo enunciado, social, mas também cultural, econômico, político etc).

No ensaio "Discurso na vida e discurso na arte", Volochínov/Bakhtin afirma que, para analisar o discurso artístico, "precisamos antes analisar em detalhes certos aspectos dos enunciados verbais ${ }^{117}$ fora do campo da arte - enunciados da fala da vida e das açôes cotidianas, porque em tal fala já estăo embutidas as bases, as potencialidades da forma artística." (Mimeo, s/d, p. 4). Assim, é possível pensar a arte massiva como qualquer outro enunciado, no embate com outros enunciados de gêneros diversos e esse exercício dialógico é fundamental para se trabalhar com a concepçâo de gênero. Afinal, um enunciado (e um gênero) se constitui de determinada maneira

117 E também os năo verbais e sincréticos - acréscimo das autoras, com base em algumas afirmaçôes do próprio Volochínov/Bakhtin que, em Marxismo e Filosofia da Linguagem, inclui, em sua primeira parte, o musical e o imagético como elementos constitutivos dos enunciados e, por esse motivo, năo devem ser desconsiderados. 
em relaçăo outros. Por isso, a questăo do cotejo é essencial como método dialéticodialógico (Paula et ali, 2011).

O filme é visto, dessa perspectiva, como gênero, com sua especificidade arquitetônica (no caso, musical), construído por um sujeito (a diretora, vista como autoracriadora), num tempo-espaço específicos (no caso de Across the Universe, o olhar contemporâneo, do século XXI sobre os anos sessentas do século XX, tomados pelo viés da contracultura, a partir das cançóes de The Beatles).

Para Bakhtin, discurso e evento săo indissociáveis, pois "o discurso verbal envolve diretamente um evento na vida, e funde-se com este evento, formando uma unidade indissolúvel." (VOLOCHINOV/BAKHTIN, Mimeo, s/d, p. 5). A linguagem surge para e no social, por isso o discurso forma uma unidade com cada evento no qual e para o qual foi gerado. $O$ enunciado e a situaçăo por ele refigurada também constituem uma relaçăo inseparável, pois "a situaçâo se integra ao enunciado como uma parte constitutiva essencial da estrutura de sua significaçăo." (idem, p. 6). 0 discurso está ligado a um evento e o enunciado, a uma situaçăo. Juntas, dialogam, vida e arte.

A enunciaçấo "bombeia energia de uma situaçâo da vida para o discurso verbal, ela dá a qualquer coisa linguisticamente estável o seu momento histórico vivo, o seu caráter único". (idem, p. 10). A singularidade do ato discursivo também é discutida por Bakhtin (2010), pois, para ele, todo evento é irrepetível e possui características particulares de um certo momento. Essa unicidade se refere às experiências vivenciadas, semiotizadas pelo enunciado, que transfigura a situaçăo da vida em discurso, com determinado acabamento e posicionamento. $O$ estudo do enunciado artístico revela-se também como um estudo do social, da vida, uma vez que a construçăo artística refigura o social (a vida), pois, como comenta Ponzio: "Os diferentes significados ideológicos, cognitivos, políticos, morais, filosóficos, entram na construçāo poética [...] na finalidade do ser figurado, e toda a organizaçâo da obra se faz em funçâo dessa figuraçâo." (2010, p. 142).

O trabalho com os gêneros discursivos, vistos em sua relativa estabilidade, de maneira viva, compostos em dadas esferas, em interaçăo com sua produçấo, circulaçăo e recepçăo, é relevante para se pensar a constituiçăo social da linguagem e do homem. Por isso, buscou-se aqui refletir sobre a compreensăo dos gêneros contemporâneos, a partir do gênero fílmico, com sua construçăo verbo-voco-visual. Para isso, partiu-se da composiçăo do filme musical, constituída por meio da síncrese com outros gêneros (em especial com a cançăo e com a música, mas năo só - no caso de Across the Universe, por exemplo, a pintura também é muito expressiva, como mencionado), a fim de pensar a construçâo enunciativa da contemporaneidade.

Um filme, tomado em sua complexidade genérica, com um olhar atento para o jogo entre a regularidade e as particularidades do enunciado, é uma ilustraçáo do trabalho com os gêneros do ponto de vista bakhtiniano. Afinal, "todo trabalho de investigaçâo de um material linguístico concreto [...] opera inevitavelmente com enunciados concretos (escritos e orais) relacionados a diferentes campos da atividade humana e da comunicaçăo." (BAKHTIN, 2011, p. 264). Voltar-se ao jogo das pequenas instabilidades que constituem a estabilidade (sempre relativa) dos gêneros é essencial se se quer trabalhar numa perspectiva bakhtiniana, que se difere da prescriçâo dos manuais acerca dos estudos e pesquisas de gêneros. Esse foi o intuito da reflexăo aqui empreendida 


\section{REFERÊNCIAS}

BAKHTIN, M. M. (VOLOCHINOV). Marxismo e filosofia da linguagem. Săo Paulo: Hucitec, 1992. 2003.

Estética da Criaçăo Verbal. Traduçăo: Paulo Bezerra. Săo Paulo: Martins Fontes, 2011.

Estética da Criaçăo Verbal. Traduçăo: Paulo Bezerra. . Săo Paulo: Martins Fontes,

Para uma filosofia do ato responsável. Săo Carlos: Pedro e Joâo, 2010.

THE BEATLES. Penny Lane. Strawberry Fields. London: Parlophone, 1966. 1 DVD.

BRAIT, B. Estilo.In:BRAIT, B. (Org.). Bakhtin: conceitos-chave. Săo Paulo: Contexto, 2010.

GRILLO, S. C. Esfera e campo. In: BRAIT, B. (Org.). Bakhtin: outros conceitos-chave. Săo Paulo: Contexto, 2010.

MACHADO, I. A. Gêneros discursivos. In: BRAIT, B. (Org.). Bakhtin: conceitos-chave. Săo Paulo: Contexto, 2010, pp. 151-166.

. O romance e a voz: a prosaica dialógica de Mikhail Bakhtin. Săo Paulo: Imago/ FAPESP, 2005.

MEDVIEDEV, P. N. 0 método formal nos estudos literários: introduçăo a uma poética sociológica. Săo Paulo: Contexto, 2012.

PAULA, L. O SLA Funk de Fernanda Abreu. 2007. 295 f. Tese. (Doutorado em Linguística e Língua Portuguesa) Faculdade de Ciências e Letras. UNESPCAr. Araraquara, 2007. Mimeo.

A intergenericidade da cançăo. Projeto de Pesquisa trienal da orientadora na UNESP. Assis-SP: UNESP, 2012 (Mimeo).

. A constituiçâo do gênero cançăo: sujeitos verbo-musicais.In: PAULA, L. de (Org.). Discursos em Perspectiva - humanidades dialógicas. Campinas: Mercado de Letras, 2014, pp. 213-242.

PAUlA, L. de; FIGUEIREDO, M. H. de; PAULA, S. L. de. O Marxismo no/do Círculo de Bakhtin.In: STAFUZZA, G. B. Slovo. Curitiba: Appris, 2011.

PONZIO, A. L. Encontro de palavras: o outro no discurso. Săo Carlos: Pedro e Joâo Editores, 2010a.

. Procurando uma palavra outra. Săo Carlos: Pedro e Joăo, 2010b.

SOBRAL, A. U. Gêneros discursivos, posiçăo enunciativa e dilemas da transposiçâo didática: novas reflexóes. Letras de Hoje, 2011. v. 46, pp. 37-45.

SERNI, N. M. Gênero discursivo cinema, o filme musical: análise dialógica de Across the Universe. 2013. 157 f. Dissertaçăo.(Mestrado em Linguística e Língua Portuguesa). Car UNESP. Araraquara, 2013.

TAYMOR, Julie. Across the Universe. Julie Taymor. EUA: Revolution Studios, 2007, 1 DVD. VOLOCHINOV/BAKHTIN. Discurso na vida e discurso na arte. s/d. Mimeo. 